\title{
Exploring the University Student Teachers' Perception of their Knowledge and Ability to Teach a Diverse Population of Learners: A Comparative Study between South Africa, Sweden and United States American College
}

Prof Anita M Dutrow

Presbytarian College, Middle and Secondary Teacher Education United States

\author{
Ms Monica Norberg \\ Lecturer in Quality Management, specialization Leadership Gotland . Uppsala University, Sweden \\ monica.norberg@hgo.se
}

Dr Mabatho Sedibe

Department of Educational Psychology, University of Johannesburg, P.O. Box 524 Aucklandpark.Johannesburg.2006. South Africa mabathos@uj.ac.za

Doi:10.5901/mjss.2014.v5n20p1701

\begin{abstract}
In this paper, a comparative study between South Africa, Sweden, and the United States, on exploring the University Student Teachers' perception of their knowledge and ability to teach a diverse population of Learners is presented. . The research design used was a comparative research methods, using descriptive statistics carried out at a University in South Africa, in Swedish University, and in an U.S. American College. Teacher students have been followed in their approaches about diversity. Both these three universities in SA, Sweden and U.S have more or less similar ideas regarding diversity in the teacher education programme. For example, students in this study have emphasized that different language groups in the classroom are beneficial to the cultural development of the class and societies. Based on this statement, it can thus be concluded by saying that internationally the perceptions on diversity in teacher education is the same, so more international comparative research should be further conducted in that regard
\end{abstract}

Keywords: Diversity. Teacher Education programme. Perceptions and Student Teachers

\section{Introduction and the Background of the Study}

In each of today's classrooms, teachers instruct a variety of students in regard to race, gender, ethnicity, cognitive development, academic achievement. In what ways can lecturers' preparation program successfully prepare young teachers to instruct learners given the diversity in the contemporary classrooms? What methodologies in teacher preparation promote confidence and skills in teacher candidates while promoting the academic achievement of students? These were some of the questions the three different researchers from three different international Universities battled with, hence the collaboration in conducting this study between South Africa, Sweden and Us

\section{Regulations about Diversity in South Africa, Sweden, and United States (U.S)}

All three countries, South Africa, Sweden, and the U.S. have government policy requirements concerning the content and experiences of teacher candidate (student teacher) preparation concerning diversity. Each is briefly discussed below:

\subsection{South Africa's (SA) Policies}

Policies such as White Paper Six (2001), the Constitution of the Republic of South Africa, Bill of Rights, Section 29(2), (1996), South African Schools' Act (SASA) of (1996) and Curriculum and Assessment Policy Statements (CAPS) Grade R-12 (2011) inform and prepare student teachers with the content and experience on diversity. These policies came into 
picture after South Africa's first democracy in 1994. These policies focus on for example equity, all learners have the right to education, no discrimination e.tc, and this means that diversity of students/learners should be respected.

A preferred Theoretical framework that exposes these student teachers to diversity in teaching is that of Brofenbrenner as stated by Donald, Lazarus and Lolwana (2002) that there are four interacting dimensions that have to be considered in understanding child development. They are person factors e.g. the temperament of the child/parent, process factors e.g. interaction that occur in a family, contexts e.g. families, schools and communities and time e.g. changes over time in the child/environment. This implies that in every teaching and learning situation the child's being and context should be a point of reference hence the consideration of diversity in order to enhance the child holistic development.

\subsection{Sweden's Policies}

The Education Act (MESS, 1985) demonstrates the law and policies how school activities shall be structured. A fundamental principle is the democratic values. The second paragraph stated that "each and every person active in the school system shall promote respect for the intrinsic value of every human being and for our common environment. Persons active in the school system shall in particular

1. promote equality between the genders, and

2. actively counteract all types of insulting treatment such as bullying or racist behaviour."

A new law, SFS 2010:800 (MESS, 2010) is being implemented and applied from 1 July 2011. The education should now be designed in accordance with the fundamental democratic values and human rights that sanctity of human life, individual freedom and integrity, the equal dignity, equality and solidarity between people. Paragraph two, presented in the last section, is now replaced with everyone who is working in education shall promote human rights and actively struggling all forms of degrading treatment.

The discrimination Act (Arbdep, 2008) stated that all individuals that conduction activities referred to the Education Act (MESS, 1985) may not discriminate against any child or pupil participating in the school activities. Age is an exception and differential treatment is appropriated and maybe also necessary to achieve the purpose.

\subsection{United State Policies}

The United States has several federal and state guidelines that address equality for students and teachers in public schools. These include legislation that focus on equal opportunities, bullying, and safety.

No Fear Act of 2002 put into words the EEO (Equal employment Opportunity) Policy: The Department of Education does not discriminate on the basis of: race, color, religion, sex, national origin, age, disability, genetic information, sexual orientation, gender identity, status as a parent, marital status or political affiliation.

The American Federation of Teachers (AFT) is launching a national bullying campaign, See a Bully, Stop a Bully. Make a Difference, focused on raising bullying awareness and providing resources, training, and technical assistance for leaders and members. AFT will be hosting regional summits, holding a series of topical seminars, and developing new materials for the campaign, and incorporating it into their Back to School efforts. AFT is also working with various organizations to amplify an anti-bullying message. AFT has accelerated their efforts during the fall of 2010 in response to heightened awareness of bullying as well as the federal guidance issued by the Department of Education detailing the obligations of local school districts and state education departments to address bullying.

In addition to the Steering Committee's work, the Health Resources and Services Administration (HRSA) has also created the Stop Bullying Now! Campaign to raise awareness about bullying, prevent and reduce bullying behaviors, identify interventions and strategies, and encourage and strengthen partnerships was developed by a steering committee and implementation work group that included more than seventy organizations from in and out of government. The campaign covers ages five to eighteen years old, and includes tool kits to encourage and empower youth to mentor younger children to take action again bullying (U.S. Department of Education)

The statutes Office of Civil Rights (OCR) enforces include Title VI of the Civil Rights Act of 19641 (Title VI), which prohibits discrimination on the basis of race, color, or national origin; Title IX of the Education Amendments of 19722 (Title IX), which prohibits discrimination on the basis of sex; Section 504 of the Rehabilitation Act of 19733 (Section 504); and Title II of the Americans with Disabilities Act of 1994 (Title II). Section 504 and Title II prohibit discrimination on the basis of disability (p. 83). Forty-five states have already passed laws addressing bullying or harassment in school. http://www.stopbullying.gov/references/white_house_conference/white_house_conference_materials.pdf\#secretary_mem 0, p. 94. 


\section{Teacher Preparation Programs and Diversity}

Below is the glimpse and discussion of teacher education preparation programs' curriculum connected to diversity in each of the three countries (SA, Sweden and US)

\subsection{South Africa's (SA) Teacher Preparation Program Curriculum and Diversity}

Post Graduate Certificate in Education (PGCE) in South Africa is regarded as a diploma in Education designed to be followed after the completion of a three year degree, majoring in Education. This is also similar with the institution where the researcher is a lecturer, but there are also students who do it from undergraduate level (BEd level) up-to the fourth year.

In the Life Orientation (LO) methodology class, the program guided by Curriculum and Assessment Policy Statement (CAPS), consists of four focus areas/themes that student teachers are expected to follow and understand the content knowledge of each at the end of the year/or end of the completion of the program. They are Personal Well-being, Citizenship Education, Recreation and Physical being and Career and Career Choices. These focus areas are integrated, all covering the concept diversity, but this diversity is looked in detailed under focus area of Citizenship Education .In this focus area (Citizenship Education) topics and activities on race, religion, culture, gender, age, ability ,language acceptance of diversity, social justice and other are emphasized. These topics further make students aware of how to accommodate and teach diverse learners in a classroom situation in order to achieve their academic goals. Student teachers are yearly given the opportunities by the teacher/lecturer to form heterogeneous groups during their class discussion activities as this will enable them to respect each other's ideas as well as to respect each other as a person irrespective of their backgrounds, language, ethnicity, age, colour and intellectual abilities. Student teachers are also given an opportunity to practice teaching at first on a micro level, through micro lessons presentation in class before they could go out into practicing how to teach at various schools of their own choice preferably within the catchment area of the university.

Lastly, the Faculty of Education's conceptual framework also adds value to diversity by emphasizing that "the Faculty of Education is committed to promote teachers who are caring, accountable and critically reflective practitioners who are able to support and nurture learning and development in diverse educational context."

\subsection{Sweden's Teacher Preparation Program Curriculum and Diversity}

The Higher Education Ordinance (HEO) states the length of the teacher training, the objects of education, and what is required for graduation (SNAHE, 1993/2011). In general, the teacher education is between three - four years depending on what kind of teacher is meant. HEO does not specific state diversity or that diversity should be a part of the education, but the teacher should learn how to communicate and gain support for society and fundamental values of democracy. However, one of the goals is to demonstrate knowledge of the importance of equality, between girls and boys, in the educational activities. The importance of individual learning is a main factor, which could be connected to diversity, and as mentioned in HEO: the training is to enable all children. The individual's strengthens and weaknesses should be the decisive factor. HEO demonstrate the necessity as a teacher to have knowledge about how to communicate, establish, and implement existing regulations designed to prevent and combat discrimination and other degrading treatment of children.

The teacher education in Sweden is under reconstruction and a new education is going to be implemented during autumn 2011 (RK, 2010). Studying the current teacher education, it does not present no clear knowledge or understanding goal about diversity or how to handle diversity in the classroom. Each school that offers teacher education can do how they want in this topic. The main purpose is to have great knowledge in specific topics.

Each university can decide the structure and construction of the teacher education, but every education should include general education area (interdisciplinary subject studies and clinical training) and specializations in a major topic and widening knowledge.

\subsection{U.S's Teacher Preparation Program Curriculum and Diversity}

Teacher Preparation programs have sought to prepare teacher candidates to teach all public school students. The teacher program is for two years. National Council for the Accreditation of Teacher Education (NCATE) has outlined standards that should be addressed in teacher preparation programs. Theories and pedagogy the address diversity, 
cultures, exceptionalities are to be embedded in fieldwork, courses, and student teaching. In addition, to understanding diversities, teacher candidates should also be successful instructors to all students and the teacher preparation unit's conceptual framework should address the successful teaching of all students. Teacher candidates are expected, by the accreditation agency, to have experiences working with all students, with faculty from diverse backgrounds, and with teacher candidates from differing cultures and exceptionalities. As outlined in Professional Standards for the Accreditation of Teacher Preparation Institutions NCATE, the indicators for a Teacher Preparation Unit that is addressing Diversity is as follows:

Standard 4: Diversity

a) Design, Implementation, and Evaluation of Curriculum and Experiences

Unit's conceptual Framework identifies curriculum, field experiences, and clinical practice. That promotes development of knowledge, skills, and professional dispositions, based on theories and knowledge bases/concepts for diversity and inclusion of ELL (English Language Learners) or ESL (English as a Second Language and Students with exceptionalities).

b) Experiences Working with Diverse Faculty

- Professional education faculty

- Faculty in other units

- School faculty from a broad range of diverse groups

c) Experiences Working with Diverse Candidates

Candidates engage in professional education experiences with candidates from the broad range of diverse groups from classes, field experiences, and clinical practice.

Reflect and analyze

d) Experiences Working with Diverse Students in P-12 Schools

- Interact with exceptional students and from diverse groups.

- Confront issues of diversity that affect teaching and student learning.

- Develop strategies for improving student learning.

Almost all coursework in the teacher education department has aspects of diversity embedded in it. In addition to these courses, candidates also complete coursework in sociology, psychology, special education. The methods and reading courses include not only theories, but instructional methods that address all learning styles, developments, and abilities. Candidates create lesson plans with accommodations for all learners.

In addition to the students coursework and public school classroom experiences that may be part of a course, teacher candidates at the institution, which Dutrow teach, have three separate fieldwork experiences. As a result of the courses, readings, seminar, and projects candidates have quite a few opportunities to learn about cultures and to practice teaching all students.

\section{Diversity in Figures and Numbers}

All the three countries, South Africa, Sweden, and U.S. have a diverse population and it is increasing. Different numbers about diversity in each country, with focus on numbers in school, students and teachers.

\subsection{South Africa's Diversity in figures and numbers}

South Africa is characterized by diverse population like other national and international countries with English and Afrikaans as official languages. South Africa is therefore a nation of diversity, with a wide variety of cultures, languages and religious beliefs. Its' complexities is that it has eleven spoken languages, meaning that it has eleven different nationalities. At this moment the government anticipates that four languages (English, Afrikaans, Sesotho sa Lebowa and Tswana) should be regarded as official languages in the near future.

See SA population on the table below as extracted from: http://www.southafrica.info/about/people/population.htm and Statistics South Africa (2011).

According to the mid-2011 estimates from Statistics South Africa, the country's population stands at 50.5-million, up from the census 2001 count of 44.8-million. There has been a growth of 10\% from 2001 to 2011 as there have been two officail censuses since South Africa's first democratic election in 1994. Africans are in the majority, making up 79.5\% of the population, while white people and coloured people each make up $9.0 \%$ and the Indian/Asian population $2.5 \%$. According to the annual mid-year estimates from Statistics South Africa, in July 2011 the country's population was 
50586 757, of which 26071721 (52\%) were female and 24515036 (48\%) were male. Africans are in the majority at 40.2-million, making up $79.5 \%$ of the total population. The white population and the coloured population are both estimated at 4.5-million (9.0\%) and the Indian/Asian population at 1.3-million (2.5\%).

Table 1

\begin{tabular}{|l|c|c|}
\hline \multicolumn{4}{c}{ Mid-Year Population Estimates 2011} \\
\hline Population group & Number & $\%$ of total \\
\hline African & 40206275 & $79.5 \%$ \\
\hline White & 4565825 & $9.0 \%$ \\
\hline Coloured & 4539790 & $9.0 \%$ \\
\hline Indian/Asian & 1274867 & $2.5 \%$ \\
\hline Total & 50586757 & $100 \%$ \\
\hline
\end{tabular}

Percentage distribution of school teachers: 2003-2004 Ethnicity All public School Teachers

\subsection{Sweden's Diversity in figures and numbers}

The Swedish government (SOU, 2008) presented a study about to what extend earlier education has prepared students in various fields of knowledge in the teaching profession. One of the areas the study investigated where how the education prepared the teacher about the diversity in the school and community. $10 \%$ of the students said that they were not prepared, $57 \%$ were to some extend prepared, and $27 \%$ were well prepared (5\% missing). These figures stated that $2 / 3$ of the students are not well prepared to meet the diversity in the classroom.

The study (SOU, 2008) discussed, not only the diversity in the classroom, which should be a factor that the teacher education has to take into account; but diversity between teachers is also something to notice. In the Swedish teacher education demanded greater ethnic and social diversity. The Swedish school shall be characterized by diversity. A requirement that teachers shall have the ability to absorb knowledge is pivotal to the development of Swedish schools (SOU, 2008). A community with social, cultural, and linguistic diversity, and a continuous influx of newly arriving pupils in school, makes new demands on the role of the teacher and teacher's competence.

Children, who were born in Sweden with at least one foreign-born parent, have increased the last 40 years from six percent to 14 percent (SCB, 2010a). From an international perspective, the proportion of foreign born in Sweden high, especially compared to other Nordic countries, which all have a foreign-born population under ten percent. In the U.S. share of foreign-born like in Sweden and 13 percent of population in the United States was born abroad.

Table 2: Sweden's population by background of birth 1970-2008.

\begin{tabular}{llccccc}
\hline Country of birth & Background & 1970 & 1980 & 1990 & 2000 & 2008 \\
\hline Sweden & & & & & & \\
& Two parents born in Sweden & 90 & 87 & 84 & 80 & 75 \\
& One parent born abroad & 3 & 4 & 5 & 6 & 7 \\
Abroad & Two parents born abroad & 1 & 2 & 2 & 3 & 4 \\
Total, \% & & 6 & 8 & 9 & 11 & 14 \\
Totalt, numbers & & 100 & 100 & 100 & 100 & 100 \\
\hline
\end{tabular}

Note: Percentage distribution and numbers in thousands (SCB, 2010a).

During the period 1970 - 2008, the number with one parent born abroad increased from 219,000 to 605,000 people (SCB, 2010a). In this group, it is common for the foreign-born parent was born in Nordic countries, Germany, and the U.S. The number of people born with two foreign-born parents has increased, 86,000 - 397,000 persons during the period $1970-2008$. At the beginning of the period it was most common with parents from a Nordic country, but over the years it has become increasingly common for people in this group have parents born in a country outside Europe with medium level of development (such as Iraq or Iran) or in Europe outside the EU (e.g. the countries of former Yugoslavia 
and Turkey).

People, who immigrates to Sweden, usually settles in great city areas such as Stockholm, Malmö/Skåne, and in the area of Kronoberg and not in rural areas such as Norrbotten and Gotland (see Table 3; SCB, 2010b).

Table 3: Statistics with proportion of foreign origin, percent.

\begin{tabular}{lcccc}
\hline County/year & 1997 & 2000 & 2005 & 2009 \\
\hline Stockholm 5,6 & 22 & 23,2 & 25 & 27,6 \\
Uppsala 3,5 & 13,4 & 13,9 & 14,9 & 16,9 \\
Södermanland 4,1 & 14,6 & 15,2 & 16,5 & 18,7 \\
Ostergötland 4,2 & 10,9 & 11,2 & 12,6 & 15,1 \\
Jönköping 5,2 & 11,1 & 12,4 & 13,9 & 16,3 \\
Kronoberg 6,1 & 10,3 & 10,8 & 12,8 & 16,4 \\
Kalmar 3,2 & 7,2 & 7,4 & 8,7 & 10,4 \\
Gotland 1,3 & 4,4 & 4,6 & $\mathbf{5 , 1}$ & $\mathbf{5 , 7}$ \\
Blekinge 4,3 & 8,2 & 8,6 & 10 & 12,5 \\
Skåne 7,2 & 15,3 & 16,6 & 19,1 & 22,5 \\
Halland 2,9 & 10 & 10,5 & 11,6 & 12,9 \\
Västra Götaland 4,6 & 14,3 & 15,3 & 17 & 18,9 \\
Värmland 3,4 & 7,8 & 8,1 & 9,6 & 11,2 \\
Örebro 4,4 & 11,6 & 12,4 & 13,9 & 16 \\
Västmanland 3,9 & 17,3 & 17,8 & 19,2 & 21,2 \\
Dalarna 2,7 & 7,7 & 7,7 & 8,6 & 10,4 \\
Gävleborg 3,3 & 7,1 & 7,2 & 8,3 & 10,4 \\
Västernorrland 2,8 & 5,7 & 5,7 & 6,8 & 8,5 \\
Jämtland 2,2 & 4,5 & 4,5 & 5,4 & 6,7 \\
Västerbotten 2,3 & 6,1 & 6,2 & 7,1 & 8,4 \\
Norrbotten 1,7 & 8,8 & 8,9 & 9,8 & 10,5 \\
\hline
\end{tabular}

Note: Breakdowned by county (SCB, 2010b)

In Sweden, the rural areas do not increase as much as other areas. Why specific areas grow faster than others are not presented and not a main factor in this study. Table 4 presents an estimated population in the coming years (SCB, 2010c).

Table 4: Current estimates of population changes

\begin{tabular}{cccccc}
\hline & 2010 & & 2015 & \multicolumn{2}{c}{2020} \\
\hline Immigration & Population & Immigration & Population & Immigration & Population \\
102874 & 9422155 & $81342^{*}$ & $9752247^{*}$ & $72608^{*}$ & $9996902^{*}$ \\
\hline
\end{tabular}

Note: *Projected. SCB (2010c)

Tabel 4 demonstrated a forecast of net immigration, which also shows that the foreign-born will increase (SCB, 2010c). With a foreign-born population, the students with another language or background than Swedish will increase. In Sweden, people with another native language are allowed to have an education in the native language. Studying how many students, who have Swedish as a second language; the numbers have increased during the last years (see Table 5; Skolverket, 2011a).

Table 5: Students with education in native language and in Swedish as a second language (SVA) school years 2006/072010/11

\begin{tabular}{ccccccc}
\hline $\begin{array}{c}\text { School } \\
\text { year }\end{array}$ & $\begin{array}{c}\text { Numbers of students } \\
\text { entitled to native language }\end{array}$ & $\begin{array}{c}\text { \% of total } \\
\text { students }\end{array}$ & $\begin{array}{c}\text { Participating in native language education } \\
\text { Total numbers of eligible } \\
\text { students }\end{array}$ & $\begin{array}{c}\text { Participating in SVA } \\
\text { students }\end{array}$ & $\begin{array}{c}\text { Total numbers of eligible } \\
\text { students }\end{array}$ & $\begin{array}{c}\text { \% of all } \\
\text { students }\end{array}$ \\
\hline $2006 / 07$ & 148674 & 15,4 & 83042 & 55,9 & 66667 & 6,9 \\
$2007 / 08$ & 155210 & 16,6 & 83482 & 53,8 & 66886 & 7,1 \\
$2008 / 09$ & 164183 & 18,1 & 87748 & 53,4 & 68289 & 7,5 \\
$2009 / 10$ & 173147 & 19,4 & 92308 & 53,3 & 71382 & 8,0 \\
$2010 / 11$ & 181412 & 20,5 & 100273 & 55,3 & 70995 & 8,0 \\
\hline
\end{tabular}

Note: Students, with at least one parent, which speaks another language at home, have the right to learn that language in 
school, native language education (Skolverket, 2011a). Students that cannot speak Swedish can apply for Swedish as a second language, and such course is for people over 16 years. Comparing the numbers of students with another background than Swedish with number of foreign-born teachers, show that these numbers do not increase in the same speed as the students (see Table 6; Skolverket, 2011b).

Table 6: Number of teachers, who are born in Sweden and abroad

\begin{tabular}{ccccccc}
\hline \multirow{2}{*}{ School year } & \multirow{2}{*}{ Personal Total } & \multirow{2}{*}{ Number } & \multicolumn{4}{c}{ whom active in \% } \\
\cline { 4 - 7 } & & & Women & Men & Born in Sweden & Born abroad \\
\hline $1999 / 2000$ & 159187 & 148636 & 69,6 & 30,4 & 92,8 & 7,2 \\
$2004 / 05$ & 178375 & 164987 & 69,5 & 30,5 & 91,7 & 8,3 \\
$2008 / 09$ & 179849 & 165772 & 69,9 & 30,1 & 90,7 & 9,3 \\
$2009 / 10$ & 174028 & 161257 & 70,1 & 29,9 & 90,6 & 9,4 \\
$2010 / 11$ & 173629 & 161781 & 70,3 & 29,7 & 90,2 & 9,8 \\
\hline
\end{tabular}

Note: Skolverket (2011b)

\subsection{U.S's Diversity in figures and numbers}

Teacher candidates need to understand the culture and learning styles of minority students. Table 7 illustrates the changing demographics in public school enrollment. As indicated and as projected the percentage of minority students will increase by ten percent from 1987 to 2020 (NCES, 2007).

Table 7: Resident population and percentage distribution, by ethnicity: Selected years and projections

\begin{tabular}{lcccccccc}
\hline \multicolumn{1}{c}{ Year/Percentage Distribution } & $1987-88$ & $1990-91$ & $1993-94$ & 2000 & 2001 & 2005 & $2010^{\star}$ & $2020^{*}$ \\
\hline White & 72 & 69.6 & 68.5 & 69.5 & 68.9 & 66.9 & 65.1 & 61.3 \\
Black/African American & 15.3 & 15.3 & 15.5 & 12.2 & 12.2 & 12.3 & & \\
Hispanic & 9.1 & 10.8 & 11.5 & 12.5 & 13.0 & 14.4 & \\
Asian/Pacific American & 2.6 & 3.0 & 3.4 & 3.8 & 3.9 & 4.3 & \\
American Indian/Alaskan native & 1.0 & 1.2 & 1.0 & 0.7 & 0.7 & 0.8 & & \\
Total Minority Enrollment & 28.0 & 30.4 & 31.5 & 30.5 & 31.1 & 33.1 & 34.9 & 38.7 \\
\hline
\end{tabular}

Note: Status and trends in the education of minorities (NCES, 2007). *Projected.

Table 6 illustrates that the minority population of public school students in U.S. is increasing (NCES, 2007). Both the Hispanic and Asian populations have both almost doubled over the last ten years. For example, the Hispanic public school student population has increased from 9.1 percent in 1987-88 school years to 14.4 percent in 2005. The Asian Pacific public school student population has increased from 2.6 percent during the 1987-88 school year to 4.3 percent during the 2005 school year. At the same time, the overall minority population has increased five percent from 28 percent in 1987-88 to 38.7 in 2005. While the population of public school students is becoming diverse, the rate at which minority students are becoming teachers is not keeping pace with the growth in the student populations.

While student populations have increased in percentages of minority students, the ethnicity of public school teachers has not increased at the same rate. The following chart (Table 8) illustrates the ethnicity of teachers in public schools (NCES, 2004). The numbers in Table 2 demonstrate that while 26.3 percent of the public school students were Black or Hispanic, only 14.1 percent of the teachers were of Black or Hispanic descent.

Table 8: Percentage distribution of school teachers: 2003-2004

\begin{tabular}{lc}
\hline Ethnicity & All public School Teachers \\
\hline White & 83.1 \\
Black, non-Hispanic & 7.9 \\
Hispanic, single or multiple races & 6.2 \\
Asian, non-Hispanic & 1.3 \\
American Indian/Alaskan native & 0.5 \\
Native Hawaiian or Pacific Islander & 0.2 \\
Multiple Races & 0.7 \\
Total Minority & 16.9 \\
\hline
\end{tabular}

Note: The distribution presented by ethnicity, percentage minority, school type, and selected school characteristics (NCES, 2004). 
The South Eastern region of the United States in terms of student and teacher populations are presented in Table 9, which illustrates a drop in White student populations and a rise in Black and Hispanics populations. For example, during the 1993-94 school year Virginia had a rise in the percentage of its minority student population from 29.8 to 36.7 percent. While many states were finding an increase in minority populations, the District of Columbia had a drop in its Black population (91.6 to 84.5 percent) and a rise in its white student population (1.5 to 5.5 percent).

Table 9: Percentage distribution of public school students in the southeastern region of the U.S.

\begin{tabular}{|c|c|c|c|c|c|c|c|c|c|c|c|c|}
\hline \multirow[t]{2}{*}{ State } & \multicolumn{2}{|c|}{ White } & \multicolumn{2}{|c|}{ Black } & \multicolumn{2}{|c|}{ Hispanic } & \multicolumn{2}{|c|}{ American Indian/Alaska native } & \multicolumn{2}{|c|}{ Asian/Pacific islander } & \multicolumn{2}{|c|}{ Minority } \\
\hline & $1993-9$ & $2003-04$ & $1993-94$ & $2003-04$ & $1993-9$ & $2003-04$ & $1993-94$ & $2003-04$ & $1993-94$ & $2003-04$ & $1993-9$ & $2003-04$ \\
\hline Alabama & 63.0 & 58.0 & 35.3 & 38.3 & 0.4 & 2.0 & 0.9 & 0.7 & 0.4 & 0.9 & 37.0 & 42.0 \\
\hline Florida & 59.2 & 52.9 & 26.0 & 25.2 & 13.4 & 20.0 & 0.1 & 0.4 & 1.3 & 1.6 & 40.8 & 47.1 \\
\hline Georgia & 59.4 & 53.6 & 37.5 & 37.6 & 1.8 & 6.6 & 0.1 & 0.2 & 1.2 & 2.1 & 40.6 & 46.4 \\
\hline Kentucky & 90.9 & 88.6 & 8.2 & 8.6 & 0.3 & 2.0 & 0.1 & 0.2 & 0.6 & 0.6 & 9.1 & 11.4 \\
\hline North Carolina & 65.8 & 61.2 & 30.8 & 29.2 & 1.2 & 6.6 & 1.3 & 0.8 & 0.9 & 2.2 & 34.2 & 38.8 \\
\hline South Carolina & 55.9 & 54.5 & 42.1 & 41.0 & 1.0 & 3.2 & 0.1 & 0.2 & 0.8 & 1.1 & 44.1 & 45.5 \\
\hline Tennessee & 75.0 & 73.0 & 23.8 & 22.6 & 0.4 & 3.1 & 0.1 & 0.2 & 0.7 & 1.2 & 25.0 & 27.0 \\
\hline Virginia & 70.2 & 63.3 & 23.9 & 28.7 & 2.7 & 4.4 & 0.1 & 0.3 & 3.1 & 3.3 & 29.8 & 36.7 \\
\hline District of Columbia & 1.5 & 5.5 & 91.6 & 84.5 & 5.8 & 8.5 & -- & -- & 0.9 & 1.4 & 98.5 & 94.5 \\
\hline
\end{tabular}

Note: Distribution of public school students by sex, ethnicity, percentage minority, and state

U.S. Department of Education, Office of education Research and Improvement, National Center for Education Statistics, 1993-4 Schools and Staffing Survey: Selected State Results; U.S. Department of Education, national Center for Education Statistics, Schools and Staffing Survey, Public School Data File, 2003-4.

Table 10 illustrates the percentage of minority students, minority teachers and minority principals and the change in the southeastern region of the U.S. between the 1993-94 school year and the 2003-04 school year.

Table 10: Percentage distribution of public school principals, teachers, students by ethnicity, percentage minority, and selected states.

\begin{tabular}{lcccccc}
\hline State & \multicolumn{2}{c}{ Minority Students } & \multicolumn{2}{c}{ Minority Teachers } & \multicolumn{2}{c}{ Minority Principals } \\
\hline & $1993-94$ & $2003-04$ & $1993-94$ & $2003-04$ & $1993-94$ & $2003-04$ \\
Alabama & 37.0 & 42.0 & 19.2 & 23.1 & 21.0 & 26.5 \\
Florida & 40.8 & 47.1 & 22.9 & 25.8 & 23.1 & 28.4 \\
Georgia & 40.6 & 46.4 & 22.9 & 22.3 & 23.1 & 24.7 \\
Kentucky & 9.1 & 11.4 & 5.7 & 4.2 & 4.3 & $4.1^{*}$ \\
North Carolina & 34.2 & 38.8 & 16.9 & 17.9 & 19.9 & 19.3 \\
South Carolina & 44.1 & 45.5 & 18.3 & 18.6 & 19.1 & 27.7 \\
Tennessee & 25.0 & 27.0 & 15.8 & 14.8 & 16.5 & 19.3 \\
Virginia & 29.8 & 36.7 & 16.3 & 18.1 & 19.7 & 19.4 \\
District of Columbia & 98.5 & 94.5 & 87.2 & 85.1 & 100.0 & 90.4 \\
\hline
\end{tabular}

Note: *Interpret data with caution. The standard error for this estimate is equal to 50 percent or more of the estimate's value

U.S. Department of Education, Office of Educational Research and Improvement, National Center for Education Statistics. 1993-4 Schools and Staffing Survey; U.s department of Education, National Center for Education Statistics, Schools and Staffing Survey, Public School Teacher Data File, 2003-4; U.S. Department of Education, National Center for Education Statistics, Schools and Staffing Survey, Public School Principal Data File, 2003-4.

The percentages of public school minority teachers and principals have increased during the ten years from 199394 to 2003-04. In the selected southeast region states represented in Table 9 South Carolina has seen an increase in minority school principals jump from 19.1 percent in 1993 to 27.7 percent in 2003. The number of South Carolina minority school teachers did not have the same increase with percentages only changing from 18.3 percent in 1993 to 18.6 percent in 2003. In general there continues to be twice as many minority students as there are teachers. The exception to this generality is the District of Columbia. In 1993 there were 100 percent minority principals and 87.2 percent minority teachers. This number almost matched the 98.5 percent minority students. However, by 2003 the minority student population had dropped from 98.5 percent to 94.5 percent and the number of minority teachers had dropped from 87.2 percent in 1993 to 85.1 percent in 2003. The number of minority principals from changed from 100 percent in 1993 to 90.4 percent in 2003 . The per cent of minority students and principals remain close with 94.5 percent minority students 
and 90.4 percent minority principals in 2003.

\section{Research Method and Design}

The research design is a comparative study, using descriptive statistics carried out at a University in South Africa, in Swedish University, and in an U.S. American College. Teacher students have been followed in their approaches about diversity. The research presentation will illustrate the need for teacher candidate who understand and can successfully teach students with diverse background. The research question is; How is the teacher candidate's perception of their knowledge of and ability to teach a diverse population of students different in South Africa and in Sweden compared to the U.S?The study has been conducted in South Africa, in Sweden and in the U.S. Participants were the student teachers who were enrolled for Post Graduate Certificate in Education (PGCE). Meaning that after their completion they will be qualified teachers who can teach in secondary and high schools. The student teachers in South Africa filled in the questionnaire based on Diversity in March 2012.

The students in Sweden did the survey the first time during 2010 and the second time during Spring 2011, at the end of the students' first semester at the university. The students in the U.S. have done it twice and with two different groups during 2009-2011. Even if the study was taken in different years in those three different countries, the researchers think that the results can still yield good response thus of value to the countries and world-wide .

\section{Results from this Study Based on the Three Different Universities in Different Countries}

The results have been divided into three main different topics:

1. Diversity and I as an individual

2. Diversity and the society, and lastly

3. Diversity and the school.

\section{Diversity and $I$ as an Individual}

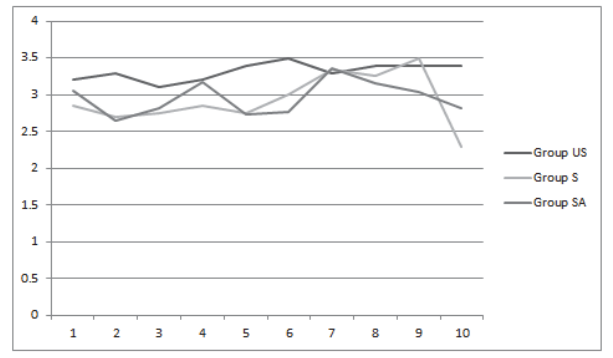

Diversity and I as an individual

1. I almost always try to understand customs of diverse cultures

2. I look for opportunities to interact with different cultures.

3. I would welcome an opportunity to live with a classmate from another country.

4. When I meet someone from an unfamiliar culture, I almost always try to find out more about their culture.

5. I would welcome an opportunity to take some of my college courses in another country.

6. Adapting to the customs of another country would not be a problem for me.

7. I enjoy hearing different languages spoken.

8. It is important for me to learn a language other than my own.

9. I would enjoy working with coworkers who are from other countries.

10. I have many friends of different ethnicities.

- Adapting to the customs of another country would not be a problem for me.

- I enjoy hearing different languages spoken

- I have many friends of different ethnicities.

Students in South Africa, Sweden, and America seem to have comparable thoughts about diversity and themselves as individuals. The only statement that really differs is the last one. The Swedish group is less agreeing with 
the statement I have many friends of different ethnicities compared to students from South Africa and the U.S. This means that SA and US are already ahead with regard to embracing diversity as compared to Sweden.

\section{Diversity and the Society}

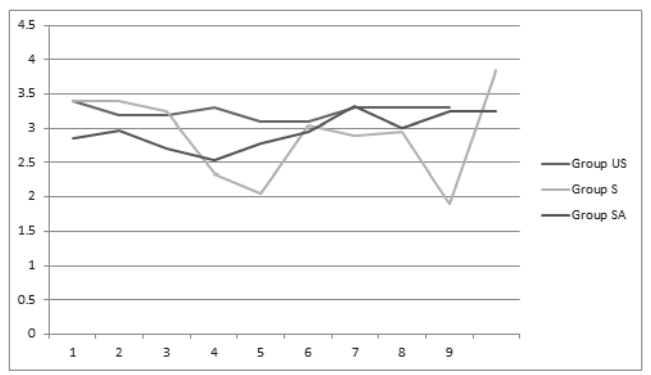

Diversity and the Society

- 1. World interests tend to be more important than the interests of my country.

- 2. I feel that in order for a person to become a citizen he/she should be willing to give up some of their loyalties to their country of origin.

- 3. Although individuality is important, excessive differences in beliefs can hurt the society.

- 4. It should not be too easy to become citizen of a new the country.

- 5. A person's work ethic tends to be related to their cultural upbringing.

- 6. I see nothing wrong with a person wishing to live in a neighborhood composed of only one ethnic group.

- 7. Citizens who have different national backgrounds should be encouraged to retain their various customs and traditions.

- 8. Some people are too insistent on retaining their customs and traditions while living in a new the country.

- 9. I am pleased that various ethnic groups raise their children in different ways.

- 10. It is important for English speaking students to learn how to speak another language.

- It should not be too easy to become citizen of a new the country.

- I see nothing wrong with a person wishing to live in a neighborhood composed of only one ethnic group.

- It is important for English speaking students to learn how to speak another language.

These ending scores reflected the belief that students in all three countries feel that it is important for English speaking students to learn how to speak another language. This implies that multilingualism is here to stay as stated by Blackledge and Creese (2010) when mentioning that in paying attention to the language practices of young people, we see new multilingualisms emerging, as the young people create meanings with their diverse linguistic repertoires.

The Swedish group is the only group that thinks it should be easy to become a citizen in a country. The Swedish group agrees less with the statement I see nothing wrong with a person wishing to live in a neighborhood composed of only one ethnic group compared to the other two groups.

\section{Diversity and the School}

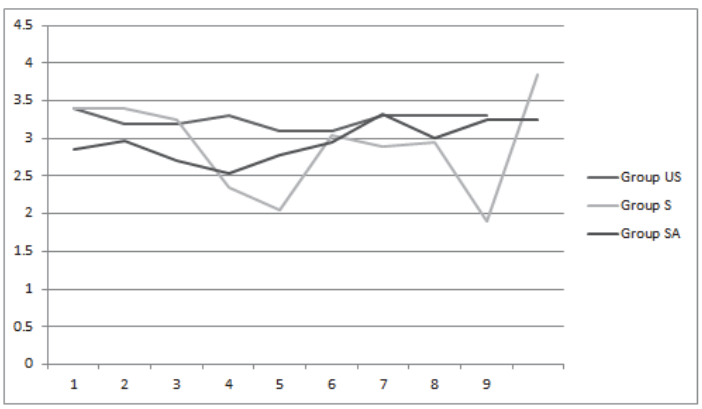


Diversity and the school

1. The different language groups in the classroom are beneficial to the cultural development of the class.

2. It pleases me to see such a great variety of religions in the classroom.

3. Students who do not speak English/Swedish should be given an opportunity in the public schools to be instructed in their native language.

4. The fact that various ethnic groups raise their children with different customs and traditions does not pose a problem to our public schools.

5. I feel that stressing different ethnic customs and traditions in public schools tends to reduce learning the basics (i.e.. reading, writing, math, etc.).

6. Public school teachers should encourage their foreign students to speak in their native language.

7. The public school curriculum, should concentrate more on the development of the society as a whole rather than on specific ethnic groups.

8. The public school system's curriculum should reflect the heritages of the different ethnic groups in our society.

9. It is necessary for the schools to use standard English/Swedish as the only language of instruction.

10. It is important to celebrate diversity in the public schools.

- it pleases me to see such a great variety of religions in the classroom.

- I feel that stressing different ethnic customs and traditions in publish schools tends to reduce learning the basics (i.e. reading, writing, math, etc.)

- The public school curriculum, should concentrate more on the development of the society as a whole rather than on specific ethnic groups

- It is necessary for the schools to use standard English/Swedish as the only language of instruction

\section{Discussions and Conclusions of this Study}

Both these three universities in SA, Sweden and U.S have more or less similar ideas regarding diversity in the teacher education programme. For example, students in this study have emphasized that different language groups in the classroom are beneficial to the cultural development of the class and societies. The students further stressed that different ethnic customs and traditions would not reduce learning the basics. Based on these statements, it can thus be concluded by saying that internationally the perceptions on diversity in teacher education is the same ,so more international comparative research should be further conducted in that regard.

\section{References}

Arbdep, Arbetsmarknads departementet. (2008). Discrimination Act (SFS 2008:567). Retrieved from http:/lwww.sweden.gov.se /content/1/c6/11/59/03/b463d1e1.pdf.

Blackledge ,A.\& Creese A. (2010). Multilingualism: A Critical Perspective. New York: Continuum, Ppix ,255.

Carter, N., E. (2003). Convergence or Divergence: Alignment of standards, assessment, and issues of diversity. AACTE Publication, Washington, D.C. ERIC ED480849.

Carter, N. E. Diversity and standards: Defining the issues. A Nation At Risk, report published by the National Commission on Excellence in Education, 1983.

Carter, N. E. \& Larke, P. Examining INTASC Standards through the lens of multicultural education: Meeting the needs of underserved students. trove.nla.gov.au/work/30063521

Cochran-Smith, M. (2004). Walking the road: Race, diversity, and social justice in teacher education. Teachers College Press, New York.

Department of Education,Education White Paper 6. (2001).Special needs Education:- Building an inclusive education and training system. Pretoria: Government Printers.

Department of Education. (2011). Curriculum and Assessment Policy Statement (CAPS) for Grade 10-12.Pretoria:Government Printers.

Donald, D. Lazarus, S. \& Lolwana, P. (2002). Educational Psychology in Social Context. Cape Town: Oxford University Press.

Dutrow, A. M. (2010). Issues of diversity in teacher preparation. ENSC. Belfast, Northern Ireland July 2010.

Dutrow, A. \& Dore, B. (2010). Field experiences for the middle level student: Early field experiences and student teaching. Current Issues in Middle Level Education, 15(1), 45-57.

Garcia, E. (2002). Student cultural diversity: Understanding and meeting the challenge. Houghton Mifflin, New York. HEO, Higher Education Ordinance (1993:100). Retrieved from http://www.hsv.se/lawsandregulations/thehighereducationordinance. 4.5161b99123700c42b07ffe3981.html.

Grant, C. \& Gillette, M. (2006). Learning to teach everyone's children. Thomson, Belmont, California.

Grant, C. (YEAR). Oppression, privilege, and high-stakes testing. Multicultural Perspectives. 6(1), 3-11. 
Hirsch, E. Jr. (1996). The schools we need and why we don't have them. Doubleday, New York.

Hirsch, E. Jr. (2000) The tests we need and why we don't quite have them. Common Knowledge, 13(1).

Hirsch, E Jr. (2006). Strategic thoughts, undelivered remarks. Philanthropy Roundtable. November 10, 2006. http://www.southafrica.info /about/people/population.htm

Love, F. E. \& Smothers, B. C. (YEAR). Compatibility of national standards for diversity with P-12 standards. Retrieved from www.eric. ed.gov/ERICWebPortal/recordDetail?accno=ED480849.

Marshall, P. L. (2002). Cultural diversity in our schools. Wadsworth, Belmont, California.

Ministry of Education and Science in Sweden. (1985). Education Act (SFS 1985:1100 with amendments to and including SFS 2000:445). Retrieved from http://www.sweden.gov.se/content/1/c6/02/15/38/1532b277.pdf.

Ministry of Education and Science in Sweden (2010). Education Act (SFS 2010:800). Retrieved from http://www.riksdagen.se /webbnav/index.aspx?nid=3911\&bet=2010:800.

NCATE, XXX (2008). It's all about student learning: Assessing teacher candidates' ability to impact P-12 students. Washington, DC 20036-1023.

NCATE, XXX (2008). Professional Standards for the Accreditation of Teacher Preparation Institutions NCATE 2008. NCATE, 2010 Massachusetts Avenue, NW, Suite 500, Washington, DC 20036-1023.

NCATE, XXX (2010) Transforming teacher education through clinical practice: A national strategy to prepare effective teachers. 2010 Massachusetts Avenue, NW, Suite 500, Washington, DC 20036-1023.

NCES, National Center for Education Statistics. (2004). Percentage distribution of school teachers: $2003-2004$ Retrieved from http://nces.ed.gov/surveys/sass/table/sass 2004 18.asp.

NCES, National Center for Education Statistics. (2007). Status and trends in the education of racial and ethnic minorities. Retrieved from http://nces.ed.gov/pubs2007/minoritytrends/table/table_1a.asp.

Republic of South Africa, Constitution, Bill of Rights, Section $29(2), 1996$. Pretoria: Government printers.

RK, Regeringskansliet. (2010). Bäst i klassen - en ny lärarutbildning [Best in class - a new teacher education]. Retrieved from http://www.regeringen.se/sb/d/11220

South African Schools' Act No .84,Section 20 (1996) pp.31-32.Pretoria:Government Printers.

SCB, Statistics Sweden. (2010a). Born in Sweden with foreign-born partents. Retrieved from http://www.scb.se/Pages/Table AndChart 296435.aspx.

SCB, Statistics Sweden. (2010b). Statistics with proportion of foreign origin, Breakdown by county. Retrieved from http://www.ssd. scb.sel.

SCB, Statistics Sweden. (2010c). Current estimates of population changes. Retrieved from http://www.ssd.scb.se/databaser/makro ISaveShow.asp.

Skolverket. (2011a). Students with education in native language and in Swedish as a second language (SVA) school years 2006/072010/11. Retrieved from http://www.skolverket.se/sb/d/1638.

SNAHE, Swedish National Agency for Higher Education. (1993/2011). Higher Education Ordinance 1993:100. Retrieved from http://www.hsv.se/lawsandregulations/thehighereducationordinance.4.5161b99123700c42b07ffe3981.html.

SOU, Statens Offentliga Utredningar. (2008). En hållbar lärarutbildning [A sustainable teacher education] 2008:109. Retrieved from http://www.sweden.gov.se/content/1/c6/11/67/37/b4b3b355.pdf.

South Africa National Census of 2011.Retrieved on the 8 November 2011.

Trotter, G. \& Rios, C. (YEAR). Preservice teacher preparation: Challenges of diversity in NCATE Accreditation. Work id: 30063521. Retrieved from http://trove.nla.gov.au/work/30063521.

U.S. Department of Education, No Child Left Behind Act of 2001.

U.S. Department of Education, Office of education Research and Improvement, National Center for Education Statistics, 1993-4 Schools and Staffing Survey: Selected State Results; U.S. Department of Education, National Center for Education Statistics, Schools and Staffing Survey, Public School Data File, 2003-4.

Whitaker, T. (2004). What great teachers do differently? Eye on Education, Larchmont: New York. 